\title{
Juventude e políticas públicas no Brasil
}

\author{
Marília Pontes Sposito \\ Universidade de São Paulo, Faculdade de Educação e Ação Educativa
}

Paulo César Rodrigues Carrano

Universidade Federal Fluminense, Faculdade de Educação Observatório Jovem do Rio de Janeiro

\section{Introdução}

Traçar um balanço das políticas públicas destinadas aos jovens no Brasil torna-se particularmente oportuno se levarmos em conta, na atual conjuntura, o novo período político inaugurado com a eleição de Luiz Inácio Lula da Silva para a presidência da República, cuja posse se deu em janeiro de 2003. Além das expectativas de mudança que sua eleição condensou, é preciso voltar o olhar para o que foi feito e considerar que já existiam no governo anterior um conjunto de iniciativas que merecem ser avaliadas para se evitar práticas que reiterem alguns dos desacertos evidentes das orientações anteriores. Mas é preciso considerar que o país também convive com mudanças expressas nas políticas de juventude que

* Artigo publicado simultaneamente em Politicas públicas de juventud en America Latina, organizado por Oscar Dávila León para Ediciones CIDPA, de Viña del Mar, Chile e apresentado na $26^{\text {a }}$ Reunião Anual do ANPEd, realizada em Poços de Caldas, MG, de 5 a 8 de outubro de 2003. nascem de iniciativas municipais diversificadas e poderão confluir para a construção de um novo paradigma em torno da questão. Mais do que nunca, orientações que integrem esses caminhos poderão contribuir para o nascimento de novas percepções em torno dos direitos de juventude. O presente artigo esboça um esforço de compreensão abrangente, de modo a situar, com base em uma concepção democrática de realização da política e de uma clara defesa dos jovens como sujeitos de direitos, os caminhos percorridos nos últimos dez anos das iniciativas focalizadas nos segmentos juvenis da sociedade brasileira. Para tanto, a partir de algumas considerações em torno do tema "Juventude e políticas públicas”, examinamos as ações federais observadas no período 1995-2002 e traçamos alguns dos caminhos percorridos no âmbito dos municípios em direção à constituição dessas políticas.

\section{Aproximações em torno do tema}

Embora recente, observa-se na sociedade brasileira um consenso inicial em torno da necessidade de 
implementação de políticas públicas ${ }^{1}$ destinadas à juventude. ${ }^{2}$ Em instigante análise sobre as ações públicas destinadas à juventude, fazendo um balanço em meados da década de 1990, Rua (1998) opta por uma definição bastante sugestiva de políticas públicas. Diz a autora: "proponho o entendimento das políticas públicas como conjunto de decisões e ações destinadas à resolução de problemas políticos" (p. 731); e con-

${ }^{1}$ Em sua acepção mais genérica, a idéia de políticas públicas está associada a um conjunto de ações articuladas com recursos próprios (financeiros e humanos), envolve uma dimensão temporal (duração) e alguma capacidade de impacto. Ela não se reduz à implantação de serviços, pois engloba projetos de natureza ético-política e compreende níveis diversos de relações entre o Estado e a sociedade civil na sua constituição. Situa-se também no campo de conflitos entre atores que disputam orientações na esfera pública e os recursos destinados à sua implantação. É preciso não confundir políticas públicas com políticas governamentais. Órgãos legislativos e judiciários também são responsáveis por desenhar políticas públicas. De toda a forma, um traço definidor característico é a presença do aparelho público-estatal na definição de políticas, no acompanhamento e na avaliação, assegurando seu caráter público, mesmo que em sua realização ocorram algumas parcerias. Neste artigo serão privilegiadas as políticas governamentais em âmbito federal e municipal.

${ }^{2}$ Não se objetiva percorrer todos os temas subjacentes à discussão dessa fase de vida. Tem sido recorrente a importância de se tomar a idéia de juventude em seu plural - juventudes -, em virtude da diversidade de situações existenciais que afetam os sujeitos. No entanto, parte dessa imprecisão parece decorrer da superposição indevida entre fase de vida e sujeitos concretos, aspectos que, por exemplo, para os estudiosos da infância não se superpõem, como afirma Attias-Donfut (1996). Infância e crianças são noções que exprimem estatutos teóricos diferentes, operação ainda não delimitada claramente pelos estudiosos da juventude, pois consideram jovens - sujeitos - e fase de vida - juventude - como categorias semelhantes. Abad (2002) propõe também uma distinção importante entre a condição (modo como uma sociedade constitui e significa esse momento do ciclo de vida) e a situação juvenil que traduz os diferentes percursos que esta condição experimenta (a partir dos mais diversos recortes: classe, gênero e etnia). trapõe à idéia de "problemas políticos"3 a expressão "estado de coisas". Assim, somente quando alcançam a condição de problemas de natureza política e ocupam a agenda pública, alguns processos de natureza social abandonam o "estado de coisas".

Essas observações são importantes para a compreensão da trajetória recente das políticas públicas destinadas aos jovens no Brasil, uma vez que, de modo diferente do conjunto da América Latina, elas tenderam a permanecer muito mais como estado de coisas do que como problemas de natureza política que demandam respostas. Por essas razões, ao examinar, sobretudo no nível federal, as políticas setoriais de educação, saúde e trabalho, Rua constata que nenhuma delas estava, naquela conjuntura, contemplando ações especialmente voltadas para os jovens: no Brasil os jovens são abrangidos por políticas sociais destinadas a todas as demais faixas etárias, e tais políticas não estariam sendo orientadas pela idéia de que os jovens representariam o futuro em uma perspectiva de formação de valores e atitudes das novas gerações.

Esse cenário passa a se alterar no final dos anos de 1990 e no início da década atual. Iniciativas públicas são observadas, algumas envolvendo parcerias com instituições da sociedade civil, e as várias instâncias do Poder Executivo - federal, estadual e municipal - são mobilizadas.

Mas o reconhecimento de consensos preliminares em torno de sua relevância na sociedade brasileira não obscurece a diversidade de orientações e pressupostos que alimentam projetos e programas destina-

${ }^{3}$ Vale ressaltar que a expressão "os jovens como problema social" tem um estatuto diferente da noção de que políticas públicas ocorrem quando jovens deixam de ser "estado de coisas" para aparecerem como "problemas políticos". Nesse último caso, tanto pode estar presente a idéia de "proteção" da sociedade diante do risco iminente provocado por seus segmentos jovens, como a percepção de que atores juvenis podem estar contemplados nas políticas enquanto expressão de um campo ampliado de direitos reconhecidos pela democracia. 
dos aos jovens. É também preciso considerar que as decisões envolvendo a implementação de políticas são amplamente produto de conflitos em torno do destino de recursos e de bens públicos limitados, ocupando um espectro amplo de negociações e de formação de consenso, mesmo que provisórios.

No caso das ações que envolvem a juventude, dois aspectos importantes precisam ser levados em conta. De um lado, a idéia de que qualquer ação destinada aos jovens exprime parte das representações normativas correntes sobre a idade e os atores jovens que uma determinada sociedade constrói; ou seja, as práticas exprimem uma imagem do ciclo de vida e seus sujeitos, como afirma Lagree (1999). No entanto, é preciso reconhecer - e essa é uma idéia relevante para a compreensão das políticas públicas recentes destinadas aos jovens no Brasil - que há uma interconexão entre aquilo que tende a se tornar uma representação normativa corrente da idade e dos jovens na sociedade e o próprio impacto das ações políticas. Dito de outra forma, a conformação das ações e programas públicos não sofre apenas os efeitos de concepções, mas pode, ao contrário, provocar modulações nas imagens dominantes que a sociedade constrói sobre seus sujeitos jovens. Assim, as políticas públicas de juventude não seriam apenas o retrato passivo de formas dominantes de conceber a condição juvenil, mas poderiam agir, ativamente, na produção de novas representações. ${ }^{4}$

${ }^{4}$ É importante recorrer a Durkheim (1970), quando afirma que as representações sociais não são a simples soma das representações dos indivíduos. Mas, neste artigo, o sentido dado à noção de representação apóia-se sobretudo em Henri Lefebvre, que recusa a dicotomia entre o que está fora, exterior (como coisa) e as representações que também vêm de dentro e são contemporâneas à constituição do sujeito, tanto na história de cada indivíduo quanto na gênese do individual na escala social. Desse modo, as representações "não são nem falsas nem verdadeiras mas, ao mesmo tempo, falsas e verdadeiras: verdadeiras como respostas a problemas 'reais' e falsas na medida em que dissimulam objetivos "reais"” (Lefebvre, 1980, p. 55).
As representações normativas, embora focadas nos jovens, não incidem apenas sobre eles, isoladamente. Elas tratam sobretudo de universos relacionais: jovens e mundo adulto, este último marcado pelo poder exercido nas instituições, nas quais as possibilidades de interação, de conflito e de solidariedade também se destacam. É preciso considerar que a disputa em torno das concepções ocorre, ainda hoje, na arena pública, protagonizada pelos vários atores, tanto jovens como adultos, que desenvolvem ações nesse segmento, incluindo nessa diversidade não só a sociedade civil como a própria composição dos aparatos do Estado.

No Brasil, ainda se observa a ausência de estudos que reconstituam os modos como foram concebidas as ações públicas destinadas aos jovens no século XX, embora, de modo geral, sejam perceptíveis algumas imagens, reiterando algumas das orientações latino-americanas.

Segundo Abad (2002), em linhas gerais, a evolução histórica das políticas de juventude na América Latina foi determinada pelos problemas de exclusão dos jovens da sociedade e os desafios de como facilitar-lhes processos de transição e integração ao mundo adulto. Ressalvando a pluralidade de enfoques, as características institucionais e a diversidade regional dos países latino-americanos, esse autor sintetiza contribuições de diversos autores e estabelece periodização em torno de quatro distintos modelos de políticas de juventude: a) a ampliação da educação e o uso do tempo livre (entre 1950 e 1980); b) o controle social de setores juvenis mobilizados (entre 1970 e 1985); c) o enfrentamento da pobreza e a prevenção do delito (entre 1985 e 2000); e d) a inserção laboral de jovens excluídos (entre 1990 e 2000).

Vive-se a simultaneidade de tempos no debate sobre a juventude, o que faz a convivência, muitas vezes dentro de um mesmo aparelho de Estado, de orientações tais como as dirigidas ao controle social do tempo juvenil, à formação de mão-de-obra e também as que aspiram à realização dos jovens como sujeitos de direitos. No que pese o maior ou o menor predomínio de determinada tendência ao longo da história, algumas 
formulações em torno dos segmentos juvenis e da juventude têm sido mais fortemente reiteradas nos últimos anos. Os jovens ora são vistos como problemas ou como setores que precisam ser objeto de atenção. Manter a paz social ou preservar a juventude? Controlar a ameaça que os segmentos juvenis oferecem ou considerá-los como seres em formação ameaçados pela sociedade e seus problemas? (Lagree, 1999).

É preciso reconhecer que, histórica e socialmente, a juventude tem sido considerada como fase de vida marcada por uma certa instabilidade associada a determinados "problemas sociais", mas o modo de apreensão de tais problemas também muda (Sposito, 1997, 2002). No artigo "De quoi parle-t-on quand on parle du 'problème de la jeunesse?'”, Bourdieu (1986) examina as ambigüidades presentes nessa expressão. As representações correntes ora investem nos atributos positivos dos segmentos juvenis, responsáveis pela mudança social, ora acentuam a dimensão negativa dos "problemas sociais" e do desvio. Assim, se nos anos 1960 a juventude era um "problema" na medida em que podia ser definida como protagonista de uma crise de valores e de um conflito de gerações essencialmente situado sobre o terreno dos comportamentos éticos e culturais, a partir da década de 1970 os "problemas" de emprego e de entrada na vida ativa tomaram progressivamente a dianteira nos estudos sobre a juventude, quase a transformando em categoria econômica (Pais, 1993; Abramo, 1997).

Por outro lado, é no âmbito de uma concepção ampliada de direitos que alguns setores da sociedade brasileira têm se voltado para a discussão da situação dos adolescentes e dos jovens, cuja expressão maior reside no Estatuto da Criança e Adolescente (ECA lei federal $\mathrm{n}^{\circ}$ 8.069), promulgado em 13 de julho de $1990 .{ }^{5}$ No entanto, parte das atenções tanto da socie-

${ }^{5} \mathrm{~A}$ Constituição federal de 1988 privilegiou a paridade de participação entre governo e sociedade civil em conselhos responsáveis por formular, gerir e estabelecer controle social sobre políticas públicas descentralizadas. A municipalização foi diretriz instituída com o intuito de estimular a participação cidadã no dade civil como do poder público voltou-se, nos últimos anos, sobretudo para os adolescentes e aqueles que estão em processo de exclusão ou privados de direitos (a faixa etária compreendida pelo ECA). Esse duplo recorte - etário (adolescentes) e econômicosocial - pode operar com seleções que acabam por impor modos próprios de conceber as ações públicas. Se tomadas exclusivamente pela idade cronológica e pelos limites da maioridade legal, parte das políticas acaba por excluir um amplo conjunto de indivíduos que atingem a maioridade mas permanecem no campo possível de ações, pois ainda vivem efetivamente a condição juvenil. De outra parte, no conjunto das imagens não se considera que, além dos segmentos em processo de exclusão, há uma inequívoca faixa de jovens pobres, filhos de trabalhadores rurais e urbanos (os denominados setores populares e segmentos oriundos de classes médias urbanas empobrecidas), que fazem parte da ampla maioria juvenil da sociedade brasileira e que podem estar, ou não, no horizonte das ações públicas, em decorrência de um modo peculiar de concebê-los como sujeitos de direitos.

As orientações defendidas pelos movimentos voltados para os direitos da infância no final da década de 1980 procuraram superar uma concepção restritiva do que é ser criança e adolescente, caminhando para uma representação que reconhece direi-

trato com a coisa pública. No contexto da referida ampliação da consciência dos direitos, a sociedade brasileira repensou a fragilidade histórica da situação das crianças e dos adolescentes, especialmente as oriundas das classes populares. O ECA é o marco legal de um processo prático-reflexivo que se dispôs a transformar o estatuto da menoridade brasileira, especialmente naquilo que se refere aos que estão em processo de exclusão social ou em conflito com a lei. O ECA, além de representar radical mudança de rumo ético-político perante o antigo ordenamento jurídico-institucional configurado no segundo Código de Menores (1979), gerou estruturas colegiadas nos âmbitos nacional - Conselho Nacional dos Direitos da Criança e do Adolescente (CONANDA) -, estadual e municipal (conselhos estaduais e municipais de direitos da criança e do adolescente). 
tos e demanda políticas dos que ainda não atingiram a maioridade. $\mathrm{O}$ estatuto legal traz em seu bojo uma nova concepção de direitos que incide fortemente sobre conservadoras formas e conteúdos de conceber jurídica, institucional e socialmente crianças e adolescentes na sociedade brasileira. Sob esse ponto de vista, as lutas sociais em torno dos direitos da infância e da adolescência ofereceram caminhos novos para a constituição de uma imagem positiva em torno de ações destinadas a esses segmentos.

O caráter inovador das representações, posto na defesa de direitos e produto dos movimentos sociais, entra em disputa com um campo dominante de significados constituídos, que imediatamente filtram, reinterpretam e restringem a percepção. Observa-se assim, nos últimos anos, uma reação conservadora às conquistas, expressando-se na pressão por mudanças na legislação ordinária e na Constituição federal - por exemplo, com propostas de diminuição da idade para se atribuir a responsabilidade penal e a demanda de providências coercitivas típicas do mundo adulto para adolescentes e crianças. ${ }^{6}$ De forma mais tênue, as resistências aparecem sob a égide de um certo temor diante do que estaria sendo considerado "excesso de direitos", fixados pelo Estatuto, e poucos "deveres" de crianças e adolescentes nas instituições escolares que, por sua vocação, deveriam acolher a todos sem qualquer tipo de discriminação.

${ }^{6}$ São frágeis as argumentações que defendem o rebaixamento da idade penal. Uma delas alega que se deveria imputar pena aos jovens a partir dos 16 anos, uma vez que com essa idade já se garante o direito ao voto. $\mathrm{O}$ argumento não considera, contudo, que esse direito não pode ser comparado ao ato infracional, por se tratar de um exercício de cidadania facultativo e que, além do mais, não permite ao adolescente ser votado. Tramitam hoje no Congresso Nacional 14 Propostas de Emenda Constitucional (PEC) e 17 Projetos de Lei (PL) de redução da idade penal. Sobre o tema, ver Goiás (2002), CONANDA - Disponível em: <http:// www.mj.gov.br/sedh/conanda> - e Associação Brasileira de Magistrados e Promotores de Justiça da Infância e Adolescência ABMP. Disponível em: <http://www.abmp.org.br/>.
Ocorre uma convivência tensa entre a luta por uma nova concepção de direitos a essa fase de vida e a reiterada forma de separar a criança e o adolescente das elites do "outro", não mais criança ou adolescente, mas delinqüiente, perigoso, virtual ameaça à ordem social.

Um segundo campo de disputas nas políticas públicas de juventude decorre das formas como são concebidas as relações entre Estado e sociedade civil na conformação da esfera pública. Tratar o tema apenas no eixo da juventude - se as políticas são para os jovens, com os jovens, por meio dos jovens com base neles -, embora importante para o debate público, do ponto de vista analítico, é insuficiente. As formulações diferenciais que pressupõem formas de interação com os atores jovens não são construídas apenas com base em uma imagem do que se pensa sobre a juventude na sociedade, mas decorrem, também, de uma clara concepção de modos de praticar a ação política, do exercício do governo (abertura ou não de canais de participação dos atores/formas de parceria etc.) e das relações com a sociedade civil na construção da esfera pública.

Mesmo no interior do aparelho de Estado, as políticas de juventude comportam diversidade de orientações e podem disputar recursos e operar diferentes definições de prioridades em face de outras políticas. Podem estar mais próximas de modelos participativos e democráticos ou serem definidos com base no que, no Brasil, tradicionalmente foi designado como cidadania tutelada, ou apenas como forma de assistência e controle do Estado sobre a sociedade, sobretudo para os grupos que estão na base da pirâmide social.

Se deslocarmos a discussão para a sociedade civil ou para os próprios segmentos jovens, o campo de disputas que opera com significados heterogêneos também ocorre. Em sua diversidade, a sociedade civil conforma, por meio de suas organizações, representações muitas vezes opostas sobre a juventude, enquanto momento do ciclo de vida, e sobre as relações dos jovens com o mundo adulto. E, finalmente, os próprios jovens são protagonistas ativos dessas disputas 
em torno dos sentidos que emprestam ao tema da juventude, pois mesmo como atores impõem significados que traduzem modos diversos de pensar a si mesmos e a seus pares, perfilam diferentemente suas demandas e estabelecem projetos pessoais ou coletivos muitas vezes reproduzindo discursos adultos dominantes no âmbito social. Por essas razões, é preciso evitar o ardil que nega o caráter natural do ciclo de vida, incorporando recortes históricos, sociais e culturais que constituem a condição juvenil na contemporaneidade, mas reintroduz esse mesmo diapasão naturalista ao considerar que a condição juvenil produz intrinsecamente concepções semelhantes sobre sua fase de vida, em nítida oposição às representações dominantes advindas do mundo adulto.

Embora articuladas, as duas dimensões de conflito - as representações normativas sobre o ciclo de vida e os formatos que assumem as relações Estado e sociedade - aqui propostas não são necessariamente complementares. Governos e demais organizações da sociedade podem ter forte vocação democrática, serem propositivos de políticas públicas no estabelecimento de canais democráticos de interação com os cidadãos, mas podem não contemplar os sujeitos jovens como um dos focos possíveis das ações e considerá-los parceiros ou segmentos para os quais estariam abertos os canais participativos. Pode ocorrer também o inverso: a formulação de políticas de juventude, mesmo consideradas em sua especificidade, é definida em um quadro de distanciamento, tutela ou subordinação da sociedade diante do Estado, em virtude das orientações prevalecentes nos governos que rebaterão diretamente sobre a forma como essas políticas vão equacionar suas relações com os segmentos juvenis.

\section{Programas federais destinados à juventude no Brasil: o que herda o G overno Lula}

No tratamento do tema da juventude, no plano das políticas federais, é preciso recompor um desenho de ações que emerge do reconhecimento de que alguns problemas afetam expressiva parcela da po- pulação jovem, sobretudo a partir da década de 1990, e a lançam numa condição que se tornou usual conceituar como sendo de risco social.

Problemas reais, identificados principalmente na área da saúde, da segurança pública, do trabalho e do emprego, dão a materialidade imediata para se pensar as políticas de juventude sob a égide dos problemas sociais a serem combatidos. Nesse processo é possível reconhecer que, em muitas formulações, a própria condição juvenil se apresenta como um elemento problemático em si mesmo, requerendo, portanto, estratégias de enfrentamento dos "problemas da juventude". Isso se expressa, por exemplo, na criação de programas esportivos, culturais e de trabalho orientados para o controle social do tempo livre dos jovens, destinados especialmente aos moradores dos bairros periféricos das grandes cidades brasileiras.

De qualquer modo, mesmo que não se possa falar na esfera federal de políticas estratégicas orientadas para os jovens brasileiros, algumas propostas foram executadas, sobretudo com base na idéia de prevenção, de controle ou de efeito compensatório de problemas que atingem a juventude, transformada, em algumas situações, num problema para a sociedade.

Ao se empreender qualquer análise sobre as iniciativas federais, é preciso evidenciar a baixa atividade coordenadora do governo federal no período 1995-2002, em relação a seus programas e projetos. Nenhum órgão da administração federal demonstrou capacidade de concentrar e publicar informações acerca das políticas de juventude. Nesse sentido, um dos primeiros diagnósticos se relaciona com a constatação da ausência de registros sobre a avaliação e o acompanhamento gerencial das políticas. O Ministério do Planejamento, Orçamento e Gestão demonstrou algum esforço na avaliação do desempenho de programas e projetos agrupados em torno dos macroobjetivos ministeriais do Plano Plurianual (20002003), mas o que foi divulgado não foi suficiente para a percepção do conjunto das ações realizadas e seus resultados na área da juventude.

A apresentação descritiva dos programas e projetos federais orientados para a juventude não tem o 
objetivo de avaliar a realidade da efetivação das políticas, uma vez que isso fugiria aos objetivos analíticos deste artigo. $^{7}$ Ainda que fosse este o propósito, tal empreitada seria dificultada pela completa ausência, na quase totalidade dos programas, de informações públicas e confiáveis sobre o desempenho das ações. Por essas razões, a meta foi a descrição das ações, buscando em seus objetivos e metodologias anunciados elementos de análise das principais tendências dos projetos e programas orientados para os jovens brasileiros nos dois últimos mandatos presidenciais.

\section{Programas e projetos federais: periodização, focos e objetivos}

Foram identificados 30 programas/projetos governamentais, incidindo com maior ou menor focalização nas faixas etárias comumente consideradas como jovens (adolescentes de 15 a 19 anos e jovens de 20 a 25), e três ações sociais não-governamentais de abrangência nacional: Programa de Capacitação Solidária, Projeto Rede Jovem e Programa Alfabetização Solidária, que surgem por indução do Programa Comunidade Solidária. ${ }^{8}$

${ }^{7}$ Os autores deste artigo enviaram correspondência a todos os ministérios, solicitando informações sobre os programas. Dois foram os resultados alcançados: o total silêncio e ausência de respostas, ou a indicação de que deveria ser consultado o site do ministério que coordenava o programa. Assim, as informações que seguem sobre os projetos e programas federais focados na juventude foram recolhidas em diversas páginas governamentais da internet, entre dezembro de 2002 e janeiro de 2003. Agradecemos a Ana Karina Brenner pelo trabalho de coleta dessas informações na internet.

${ }^{8}$ Dos 30 programas estritamente governamentais, cinco se localizavam no Ministério da Educação, seis no Ministério de Esporte e Turismo, seis no Ministério da Justiça, um no Ministério de Desenvolvimento Agrário, um no Ministério da Saúde, dois no Ministério de Trabalho e Emprego, três no Ministério de Previdência e Assistência Social, dois no Ministério de Ciência e Tecnologia, dois no Gabinete de Segurança Institucional da Presi-
É preciso assinalar, desde já, que a quantidade de programas/projetos em um mesmo ministério não se apresentou como garantia de maior atenção e qualidade de ação na questão da juventude. O Ministério da Saúde, por exemplo, possui um único e longevo programa no qual as ações se mostram institucionalmente orgânicas, racionalmente focalizadas, refletidas teoricamente e articuladas com redes governamentais e da sociedade civil. Entretanto, o Ministério dos Esportes, que contava com seis programas, demonstrou baixa capacidade de coordenação de suas ações, incipiente reflexão sobre a problemática juvenil e baixíssima sinergia com atores coletivos da sociedade civil.

Em relação ao tempo de início das ações relacionadas com jovens em curso nos diferentes ministérios, no momento deste estudo, considerando o início do primeiro governo do ex-presidente Fernando Henrique Cardoso, em 1995, foi estabelecida a seguinte classificação temporal: 1) antes de 1995; 2) entre 1995 e 1998; 3) entre 1999 e 2002; e 4) sem informações. Somente três programas são anteriores ao primeiro Governo FHC. ${ }^{9}$

No período do primeiro mandato (1995-1998) foram criados seis programas. ${ }^{10}$ Entre 1999 e 2002 ocorreu ativação de 18 programas para o setor, número significativo para o período estudado, representando uma verdadeira explosão da temática juventude e adoles-

dência da República, um no Gabinete do Presidente da República (Projeto Alvorada) e, por último, um de caráter interministerial especificamente voltado para a integração das ações de 11 projetos/programas focados em jovens, localizado no Ministério de Planejamento, Orçamento e Gestão (Programa Brasil em Ação).

${ }^{9}$ Programa Saúde do Adolescente e do Jovem (Ministério da Saúde), Programa Especial de Treinamento (PET - Ministério da Educação) e Prêmio Jovem Cientista (Ministério da Ciência e Tecnologia).

${ }^{10}$ Jogos da Juventude; Esporte Solidário (ambos do Ministério dos Esportes e Turismo); PRONERA (Ministério do Desenvolvimento Agrário), PLANFOR (Ministério do Trabalho e Emprego), Capacitação Solidária e Alfabetização Solidária (Presidência da República / Conselho Comunidade Solidária). 
cência no plano federal, ainda que esta tenha ocorrido num quadro de grande fragmentação setorial e pouca consistência conceitual e programática. ${ }^{11}$

A identificação dos referidos 33 programas que incidem sobre a juventude no âmbito federal é acompanhada também da constatação de que os mesmos não constituem uma totalidade orgânica naquilo que se refere à sua focalização no segmento jovem. Na análise do público a que se destinam, pode-se dizer que existem focos fortes, médios ou de fraca intensidade, sendo distribuídos da seguinte forma: a) o foco dirige-se explicitamente a adolescentes e/ou jovens (18 programas ou projetos); b) o foco é difuso entre crianças e adolescentes ou jovens e adultos (10 programas); e c) o foco dirige-se à população jovem apenas de modo incidental (cinco programas).

A classificação acima permite intuir, também, a falta de consenso, no âmbito federal, sobre a necessidade da definição de políticas específicas e coordenadas para a juventude. O pouco acúmulo teórico so-

${ }^{11}$ Projeto Escola Jovem, Financiamento Estudantil e Programa Recomeço (Ministério da Educação); Olimpíadas Colegiais, Projeto Navegar e Esporte na Escola (Ministério do Esporte e Turismo); Serviço Civil Voluntário, Plano Nacional de Enfrentamento da Violência Sexual, Programa de Defesa dos Direitos da Criança e do Adolescente e Programa Paz nas Escolas (Ministério da Justiça); Jovem Empreendedor (Ministério do Trabalho e Emprego); Centros da Juventude e Agente Jovem de Desenvolvimento Social e Humano (Brasil Jovem - Ministério da Previdência e Assistência Social); Prêmio Jovem Cientista do Futuro (Ministério da Ciência e Tecnologia), PIAPS e CENAFOCO (Gabinete de Segurança Institucional da Presidência da República), Brasil em Ação (Ministério do Planejamento, Orçamento e Gestão), Projeto Alvorada (Presidência da República). Cinco programas não ofereceram informações sobre a data do início de suas atividades: Programa de Apoio ao Aluno Estrangeiro (Ministério da Educação), Reinserção Social do Adolescente em Conflito com a Lei (Ministério da Justiça), Combate ao Abuso e Exploração Sexual (Ministério do Esporte e Turismo), Projeto Sentinela (Ministério da Previdência e Assistência Social) e Projeto Rede Jovem (Comunidade Solidária). bre essa problemática se expressa na elaboração de significativo número de programas e projetos que se destinam indistintamente a crianças, adolescentes e jovens. Nesse quadro de heterogeneidade de parâmetros sobre a dimensão etária da juventude, a infância pode se alargar até aos 14 anos de idade e o jovem ser designado como maior de 10 anos de idade. ${ }^{12}$

A seguir será apresentada apenas a descrição dos 18 programas/projetos federais, divididos por pasta ministerial, e cujo foco do direcionamento das ações para adolescentes e/ou jovens pode ser considerado forte.

\section{Ministério da Educação}

\section{Programa de Estudantes em Convênio de Graduação (PEC-G)}

O programa é destinado a cidadãos estrangeiros, entre 18 e 25 anos de idade, com ensino médio completo, preferencialmente os que estejam inseridos em programas de desenvolvimento socioeconômico acordados pelo Brasil por via diplomática. Tais programas definem o compromisso do aluno de regressar ao seu país e contribuir com a área na qual se graduou, sendo desenvolvido em parceria com o Ministério das Relações Exteriores.

\section{Projeto Escola Jovem}

O objetivo geral incidia sobre a implementação da reforma e a ampliação da oferta de vagas para o ensino médio. O Projeto foi iniciado em março de 2001, apontando como um de seus desafios a construção de uma escola para jovens e jovens adultos que preservasse sua identidade com os jovens e su-

\footnotetext{
${ }^{12} \mathrm{O}$ primeiro exemplo é o caso do Programa de Erradicação
} do Trabalho Infantil (PETI), cuja população alvo se estende até aos 14 anos. O segundo exemplo é o Programa Saúde do Adolescente e do Jovem, que circunscreve a juventude brasileira na ampla faixa que vai de 10 a 24 anos. 
perasse os baixos rendimentos escolares. Foram estabelecidos critérios de elegibilidade para os estados participarem do programa, tais como: "ser uma escola para jovens e jovens adultos", apresentar práticas de correção de fluxo e demonstrar sustentabilidade para custos adicionais além daqueles financiados pelo programa. O Escola Jovem foi subdividido em dois subprogramas: a) projetos de investimentos nas unidades da federação que destinava recursos financeiros aos estados para a implementação da reforma, a melhoria da qualidade e a expansão da oferta de ensino médio e a realização de projetos juvenis; e b) políticas e programas nacionais com o objetivo de fomentar e apoiar a implementação da reforma do ensino médio nos estados e no Distrito Federal.

O governo federal teve baixa contribuição orçamentária no orçamento global desse projeto, parcialmente financiado pelo Banco Interamericano de Desenvolvimento (BID) e pelos estados da Federação. ${ }^{13}$ Apesar de contemplar no seu título um aspecto inovador, ao trazer a categoria juventude para a análise da condição de aluno, o programa limitou-se na prática a distribuir alguns computadores, sendo ineficaz no seu conjunto. A própria reforma foi alvo de profundas críticas da comunidade acadêmica (Kuenzer, 2000a, 2000b; Ferretti, 2000).

\section{Ministério do Esporte e Turismo}

\section{Jogos da Juventude}

O programa Jogos da Juventude, criado no ano do 1995, sofreu uma interrupção em 1999, sendo retomado em 2001. Visa à promoção da prática de atividades esportivas entre os jovens na perspectiva do denominado esporte de rendimento. A competição é utilizada como meio de descoberta e aprimoramento

${ }^{13}$ De um total de 1 bilhão de dólares, 500 milhões são do BID, 450 milhões das unidades da Federação e 50 milhões da União, esses últimos destinados exclusivamente à gestão nacional do projeto. de novos talentos para o desporto nacional. Os campeões dos jogos estaduais compõem as equipes dos jogos nacionais, momento em que os técnicos das diferentes seleções esportivas brasileiras podem observar e selecionar novos atletas.

\section{O limpíadas Colegiais}

Criado no início de 2000, tem como público-alvo adolescentes de 12 a 14 anos e jovens de 15 a 17 anos. Seus objetivos são o fomento do desporto escolar, o intercâmbio sociodesportivo no país e o desenvolvimento do potencial esportivo brasileiro. Procura também demonstrar à comunidade esportiva internacional a capacidade de organização esportiva do Brasil com vistas à capacitação de grandes eventos internacionais. Os estados são estimulados a incrementar suas infra-estruturas para receber os eventos esportivos do programa. As Olimpíadas Colegiais são apresentadas como ação conjunta do Ministério do Esporte e Turismo com o Ministério da Educação e o Comitê Olímpico Brasileiro. Ainda que no texto de sua apresentação sejam ressaltados o caráter lúdico e a idéia de congregação, as Olimpíadas Colegiais são pensadas também como espaço de revelação de talentos, o que confirma a hegemonia do esporte de rendimento sobre o denominado esporte-educação. Os objetivos do programa deixam transparecer que a preocupação principal é com o desenvolvimento esportivo do país. A juventude, também nesse caso, não se apresenta como uma categoria central da organização e do desenvolvimento da proposta.

\section{Projeto N avegar}

Destinado a adolescentes de 12 a 15 anos residentes em comunidades ribeirinhas, lacustres e costeiras, o Projeto Navegar teve início em 1999. Seu objetivo principal é difundir e democratizar o acesso a esportes náuticos, priorizando os adolescentes moradores em áreas de risco social e matriculados na rede pública de ensino. Em 2002, era registrada a existência de 37 núcleos do Projeto em 18 estados. 


\section{Ministério da Justiça}

\section{Serviço Civil Voluntário}

Criado em dezembro de 1997, é destinado aos jovens de 18 anos que optaram por não se alistar no serviço militar obrigatório e também aos que foram dispensados. É concebido como "um rito de passagem para a maioridade", com ênfase em dois aspectos: a preparação do/a jovem para o trabalho e para a cidadania, entendida como uma participação social solidária em uma sociedade democrática. As atividades desenvolvidas organizam-se em torno dos direitos humanos, da qualificação profissional, da elevação da escolaridade e da prestação de serviços à comunidade. ${ }^{14}$ Participaram do programa 2.500 jovens beneficiados com recursos do Plano Nacional de Segurança Pública, somados a 22.000 jovens beneficiados com recursos do Fundo de Amparo ao Trabalhador (FAT) repassados às secretarias estaduais de trabalho e emprego e a organizações não-governamentais.

\section{Programa de Reinserção Social do Adolescente em Conflito com a Lei}

Desenvolvido no Departamento da Criança e do Adolescente, da Secretaria de Estado de Direitos $\mathrm{Hu}$ manos, possui âmbito nacional, sendo dirigido a adolescentes em conflito com a lei que cumprem medidas judiciais socioeducativas não-privativas da liberdade. Sua missão é articular e estimular os esforços do sistema socioeducativo instituído pelo Estatuto da Criança e do Adolescente. Essa iniciativa foi apresentada como uma resposta institucional a propostas de ações governamentais de proteção ao adolescente em situação de conflito com a lei consignadas no Programa Nacional de Direitos Humanos. É

${ }^{14}$ O Serviço Civil Voluntário é definido como sendo de abrangência nacional, porém, as informações disponíveis davam conta de sua realização somente nos municípios das regiões metropolitanas de Recife, Vitória, Rio de Janeiro, São Paulo, Curitiba e Distrito Federal. importante assinalar que um dos marcos desse programa foi a opção política de ênfase em medidas socioeducativas em meio aberto, implementando aquilo que é preconizado pelo ECA, em detrimento às medidas privativas de liberdade.

\section{Promoção de Direitos de Mulheres Jovens Vulneráveis ao Abuso Sexual e à Exploração Sexual Comercial no Brasil}

Essa ação, criada em 1999, integra o Programa de Defesa dos Direitos da Criança e do Adolescente e tem como objetivo promover os direitos das jovens, especialmente daquelas em situação de risco, visando eliminar a violência cometida contra elas. O públicoalvo compreende, assim, as jovens brasileiras violentadas sexualmente nos primeiros anos de vida e as meninas que trocam "favores" sexuais pela própria sobrevivência.

\section{Ministério da Saúde}

\section{Programa de Saúde do Adolescente e do Jovem}

As iniciativas na área de saúde remontam a 1989, quando o Ministério da Saúde voltou-se para a saúde do adolescente com a criação do Programa Saúde do Adolescente (PROSAD). Em 1999, foi criada a Área de Saúde do Adolescente e do Jovem (ASAJ), no âmbito da Secretaria de Políticas de Saúde. Essa nova área, então, tornou-se responsável pela articulação dos diversos projetos e programas do Ministério da Saúde que lidam com questões relativas à adolescência e à juventude, em decorrência da percepção da necessidade de uma política nacional integrada de atenção específica aos indivíduos de 10 a 24 anos. ${ }^{15}$ É importante destacar, além do desenvolvimento de ativida-

\footnotetext{
${ }^{15}$ São áreas de atuação: crescimento e desenvolvimento;
} sexualidade; saúde mental; saúde reprodutiva (gravidez na adolescência); saúde do escolar adolescente; prevenção de acidentes; violência e maus-tratos; família. 
des relacionadas com a promoção da saúde dos adolescentes e dos estudos temáticos, a preocupação expressa pelo programa em contribuir com atividades intra e interinstitucional, nos âmbitos governamentais e não-governamentais, visando à formulação de uma política nacional para a adolescência e a juventude, a ser desenvolvida nos níveis federal, estadual e municipal. Reconhece-se que muitas das intervenções voltadas para a melhoria da saúde do adolescente falharam em virtude do foco estreito e da desarticulação das iniciativas governamentais. Também é digno de nota o crítico reconhecimento do programa sobre a pouca participação dos jovens no planejamento, na implementação e na avaliação das atividades oriundas de políticas públicas.

\section{Ministério do Trabalho e Emprego}

\section{Jovem Empreendedor}

Esse programa foi criado no segundo mandado do presidente Fernando Henrique Cardoso, destinando-se à capacitação profissional e posterior financiamento de jovens de nível técnico, em fase de conclusão de curso ou recém-formados, com idade entre 18 e 29 anos, interessados em dirigir o próprio negócio. Teve focalização regional, limitando-se às áreas de atuação do Banco Nordeste (norte do Espírito Santo, Minas Gerais e estados do Nordeste), responsável por seu desenvolvimento. Segundo avaliação de macroobjetivos do Plano Plurianual (PPA) pelo Ministério do Planejamento, o programa teve um desempenho nulo, pois não houve a execução financeira prevista, nem tampouco realização de metas físicas que dispensassem recursos. O público-alvo do programa Jovem Empreendedor foi abrangido pelo Programa de Geração de Emprego e Renda (PROGER), apesar de este não promover nenhuma focalização especial para o jovem. ${ }^{16}$

${ }^{16}$ O Ministério do Trabalho e Emprego (MTE) demonstrou preocupações em desenvolver um sistema de acompanhamento que pudesse captar as informações relativas ao usuário do programa, em especial ao jovem.

\section{Ministério da Assistência e Previdência Social}

Esse ministério lançou, no segundo mandato do governo FHC, o Programa Brasil Jovem, compreendendo ações de implantação dos Centros da Juventude e a capacitação de jovens de 15 a 17 anos como Agente Jovem de Desenvolvimento Social e Humano, mediante a concessão de bolsa.

As ações desse programa como um todo se voltaram para os jovens entre 14 e 25 anos em "condições de vulnerabilidade social”. A prioridade de implementação incidiu sobre municípios com as seguintes características: alto índice de jovens de famílias de baixa renda; alto índice de doenças sexualmente transmissíveis e AIDS entre os jovens; exposição dos jovens ao uso e ao comércio de drogas; alto índice de mortalidade juvenil por causas externas; exploração sexual de meninas e jovens; alto índice de gravidez na adolescência; taxa elevada de desocupação juvenil, ou seja, jovens fora da escola e de qualquer forma de trabalho; taxa de analfabetismo e baixo índice de escolaridade.

\section{Centros da Juventude}

Os centros deveriam funcionar como pólos de distribuição de informações sobre programas, projetos e serviços nas áreas de saúde, educação, cultura, capacitação para o trabalho, esporte, proteção, justiça e assistência social. Teriam como objetivo estabelecer conexões entre a oferta e a demanda desses serviços, apoiando a juventude local na busca de soluções para os seus problemas. A informação, o esporte e a cultura são apontados como o tripé de sustentação da agenda das atividades. Os Centros da Juventude foram, assim, concebidos para serem de responsabilidade do governo local, dos jovens e da comunidade.

Em suas diretrizes recomenda-se que a gestão da programação e das atividades seja feita de forma participativa com a "comunidade" e que sejam estabelecidas parcerias com organizações nãogovernamentais. O projeto previa repasses financeiros decrescentes, ao longo de quatro anos, por parte da 
Secretaria de Estado de Assistência Social (SEAS) para determinado município ou estado, da ordem de 20 mil reais no primeiro ano, 15 mil no segundo, 10 mil no terceiro e 5 mil no quarto ano. Os repasses decrescentes foram concebidos como estratégia de indução da auto-sustentabilidade progressiva do programa no âmbito local, ou ainda uma retirada progressiva da presença federal ante os municípios que adotaram essa política para a juventude. ${ }^{17}$

\section{Agente Jovem de Desenvolvimento Social e Humano}

Os jovens destinatários do programa deveriam ser alfabetizados e carentes, vivendo em famílias cuja renda per capita não ultrapassasse meio salário mínimo. Os municípios habilitados a participar do programa deveriam ser capitais dos estados - isso em função do diagnóstico da maior concentração de jovens e da maior prevalência de problemas envolvendo essa faixa etária - e possuir menor Índice de Desenvolvimento Humano (IDH) em relação à média regional. Em termos gerais, o programa objetiva preparar o jovem para a atuação intergerencial, procurando capacitá-lo para o mercado de trabalho e também para atuar em suas comunidades na área de saúde, cultura, meio ambiente, cidadania, esporte e turismo. Dentre os principais objetivos específicos destacam-se: a) estimular o jovem para o desenvolvimento do seu papel de protagonista na sociedade; $b$ ) mostrar a esse jovem que é possível planejar e construir seu próprio futuro; c) fazer com que esse jovem se supere e se prepare para atuar de modo cooperativo na transformação da própria comunidade onde vive; d) resgatar vínculos familiares, comunitários e sociais; e) reverter indicadores sociais pela ação corretiva e preventiva; f) inserir e reinserir o jovem no sistema educacional. Os jovens participantes deveriam freqüentar um curso de capacitação durante seis

${ }^{17}$ Trata-se de uma iniciativa sem maiores informações sobre as ações que foram, de fato, efetivadas. meses, para depois começarem a atuar em sua comunidade. Durante esse período, receberiam uma bolsa mensal no valor de 65 reais.

O Programa Agente Jovem, em seu início, não contou com destinação orçamentária própria, uma vez que não foi previsto no PPA do período 2000-2003. Entretanto, segundo avaliação governamental, as parcerias realizadas entre a Secretaria Especial de Assistência Social com estados, municípios, organizações não-governamentais e com o empresariado teriam garantido o êxito do programa e superado as expectativas de seus formuladores.

\section{Ministério da Ciência e Tecnologia (CN Pq)}

\section{Prêmio Jovem Cientista}

Criado em 1981, o prêmio destina-se a graduados em curso superior que têm menos de 40 anos e estudantes de escolas técnicas e/ou curso superior com menos de 30 anos de idade. O objetivo é estimular a revelação de talentos e investir em estudantes e profissionais que procuram alternativas para problemas brasileiros. O prêmio tem vida longa, se comparado com as demais ações federais. Registrou-se somente breve interrupção por dois anos (1986 e 1987). Os temas do prêmio são sempre inéditos - ligados à saúde, à agricultura, à qualidade dos alimentos e da água, à energia, às telecomunicações, à indústria civil, à reciclagem de rejeitos industriais e aos recursos humanos. Naquilo que se refere ao segmento jovem, esse programa possui uma delimitação expressivamente elástica, uma vez que estende o conceito de juventude à faixa dos 40 anos de idade, afastando-se de qualquer outra classificação etária estabelecida nos demais programas e projetos governamentais.

\section{Prêmio Jovem Cientista do Futuro}

Criado em 1999, destina-se exclusivamente a alunos do ensino médio. Concebido nos moldes do Prêmio Jovem Cientista, apresenta a pesquisa como uma fonte de aprendizagem e produção de conhecimento. 
Seu objetivo é despertar o interesse dos jovens na carreira científica e tecnológica.

\section{Presidência da República Comunidade Solidária ${ }^{18}$}

\section{Programa Capacitação Solidária}

Concebido como alternativa para enfrentar o problema de desemprego dos jovens de baixa escolari-

${ }^{18}$ O Programa Comunidade Solidária foi criado em 1995 por decreto presidencial e coordenado durante dois mandatos consecutivos pela primeira-dama, Ruth Cardoso. Peça chave da estratégia implantada para as políticas sociais do governo de Fernando Henrique Cardoso, suas prioridades foram: criação e geração de renda, apoio ao desenvolvimento do ensino básico e defesa dos direitos e promoção social das crianças e adolescentes no Brasil. Seu escopo principal foi o de se constituir em novo modelo de ação social utilizando o conceito-força de articulação solidária da sociedade na mobilização de recursos humanos, técnicos e financeiros para o combate à pobreza e à exclusão social. Para a realização da referida articulação foi criada uma secretaria executiva para integrar as administrações federal, estaduais e municipais e buscar tornar mais eficientes as políticas sociais do governo. Criouse também o Conselho da Comunidade Solidária, órgão assessor não-governamental, desprovido de orçamento próprio e composto por 21 representantes da sociedade civil e 11 ministros de Estado. Esse conselho, concebido para favorecer a interação entre o governo e a sociedade, teve presença ativa nas decisões que envolveram as políticas sociais. Foi criada, ainda, a organização não-governamental Associação de Apoio ao Programa Capacitação Solidária (AAPCS), que ficou com a responsabilidade de captar recursos de pessoas físicas ou jurídicas nacionais e internacionais para aplicá-los na gestão, implementação e desenvolvimento do Programa de Capacitação Solidária destinado a jovens de 16 a 21 anos. É preciso assinalar que o Programa Comunidade Solidária, ainda que não tenha tido a efetividade e o grau de consolidação institucional pretendidos, expressou determinada concepção de política pública de combate à pobreza que teorizou o compartilhamento democrático de ações entre Estado e sociedade civil, mas praticou a confusão de responsabilidades sociais públicas e priva- dade e implementado a partir de 1996, focaliza suas ações na capacitação profissional de jovens de 16 a 21 anos, provenientes de famílias de baixa renda residentes nas grandes regiões metropolitanas. Um de seus objetivos seria o fortalecimento das organizações da sociedade civil através de atividades e cursos voltados para o desenvolvimento de competências e aperfeiçoamento de gestores sociais. Os projetos de cursos promovidos por organizações sociais eram selecionados por concurso e financiados pelo programa. ${ }^{19}$

\section{Rede Jovem}

O Projeto Rede Jovem foi uma iniciativa do Conselho da Comunidade Solidária e do Ministério da Ciência e Tecnologia, com o objetivo de identificar o que seus formuladores definiram como "as condições propícias que subsidiem iniciativas do Estado e da sociedade civil para integrar jovens - especialmente aqueles em situação de risco social - de forma sustentada e permanente, como protagonistas, por meio da informática e da internet, valorizando e fortalecendo suas formas de expressão, criatividade e participação na sociedade" (disponível em <www.redejovem.org.br>). O objetivo específico foi o de "conectar jovens, dandolhes um instrumento de integração e comunicação" como forma de lhes permitir a superação da atual con-

das promovendo a transferência de prerrogativas governamentais e recursos orçamentários a entes privados assistenciais stricto sensu e empresariais que assumiram o discurso da responsabilidade social. Em 1999, o Conselho da Comunidade Solidária avaliou sua trajetória com vistas a reformular sua estrutura e a projetar sua continuidade. No novo desenho, figurou como uma das missões do conselho o apoio à promoção do Desenvolvimento Local Integrado e Sustentável. A análise do Programa Comunidade Solidária foge aos objetivos deste trabalho; para mais informações consultar: <http://www.rededlis.org.br>.

${ }^{19} \mathrm{O}$ edital do concurso incluía modelo para a formulação dos projetos e formato indicado para os cursos com um módulo básico (leitura, comunicação, cálculo e escrita) e um módulo específico, voltado para o aprendizado de uma habilidade de geração de renda. 
dição de isolamento, especialmente os jovens das grandes metrópoles que estariam excluídos e desinformados. O público-alvo foi, então, o de jovens de baixa renda que não têm acesso à internet, mas que teriam condições de ampliar, pela via virtual, seus contatos e a troca de informações relevantes sobre saúde, direitos e formação profissional. O projeto concebeu o conceito de "espaço jovem", local físico no qual se encontrariam disponíveis computadores conectados à internet com a função de oferecer aos jovens alternativas de lazer, aprendizado, conhecimento, perspectivas profissionais e estímulos à criatividade. O "espaço jovem" funcionaria, então, como uma espécie de telecentro de informática necessariamente conectado à internet como forma de promover a integração virtual entre os jovens. O projeto foi formulado para ser executado em parceria com organizações sociais.

Assim como nas demais ações do consórcio público/privado do Programa Comunidade Solidária, torna-se difícil identificar a real presença do poder público nos relatos sobre a iniciativa, ainda que a formulação inicial propugne o subsídio a iniciativas de parcerias entre o Estado e a sociedade civil. ${ }^{20}$

\section{Ministério do Planejamento, O rçamento e G estão}

\section{Brasil em Ação/Grupo Juventude}

O Programa Brasil em Ação, criado em 2000, no Ministério do Planejamento, Orçamento e Gestão, também denominado Grupo Juventude, foi um programa-piloto de coordenação de grupo de programas de atendimento à juventude (jovens na faixa etária de 15 a 29 anos), abrangendo seis ministérios, 11 pro-

${ }^{20} \mathrm{Na}$ internet (disponível em: http://<www.redejovem.org.br>), o projeto Rede Jovem é anunciado como uma iniciativa da "Comunitas - Parcerias para o Desenvolvimento Solidário”, organização social responsável pela manutenção de 15 Espaços Jovens instalados em dez cidades de sete estados brasileiros (BA, CE, DF, ES, PE, RJ, SP). gramas $^{21}$ e suas interações com governos estaduais. O Brasil em Ação foi desenvolvido no âmbito da estratégia do Programa Avança Brasil, destinado a promover a integração das ações governamentais com o mesmo público-alvo ou no mesmo espaço geográfico específico de atuação. A avaliação do Ministério do Planejamento, após o primeiro ano de funcionamento desse programa, indicou, como resultado geral, que o trabalho permitiu que os gerentes dos programas do Avança Brasil conhecessem seus pares e os programas correlatos, o que teria possibilitado uma visão mais global da questão da juventude no conjunto da administração federal. Mesmo com essa positiva (ainda que genérica) avaliação, o Ministério do Planejamento alertou para a inadequação do tamanho do grupo e a qualificação da equipe responsável pelo gerenciamento e também para as dificuldades de participação no processo de programação financeira dos coordenadores, o que comprometia a execução do Programa Avança Brasil.

A constituição desse grupo de coordenadores de programas e projetos de juventude, ainda que não tenha apresentado produtos significativos, indica certo grau de consciência da administração federal sobre a fragmentação das ações na área da juventude. A continuidade desse tipo de ação poderia se constituir numa protopolítica facilitadora, talvez, de níveis superiores de instituição de políticas coordenadas.

\section{U ma perspectiva de análise das ações federais}

As primeiras ações de programas específicos destinados aos jovens, sobretudo adolescentes, aparecem no interior da área da saúde e são marcadas pelo foco na prevenção (DST/AIDS), drogação, aci-

${ }^{21}$ Educação de Jovens e Adultos, Esporte Solidário, Paz nas Escolas, Qualificação Profissional do Trabalhador, Centros da Juventude, Reinserção do Adolescente em Conflito com a Lei, Defesa dos Direitos da Criança e do Adolescente, Direitos Humanos, Direito de Todos, Saúde de Jovem, Desenvolvimento do Ensino Médio e Desenvolvimento da Educação Profissional. 
dentes de trânsito e gravidez precoce), já ao final da década de 1980, com a criação do Programa Saúde do Adolescente (PROSAD), no âmbito do Ministério da Saúde, antes mesmo do primeiro mandato do presidente Fernando Henrique Cardoso.

A disseminação das mortes violentas de jovens ou por eles protagonizadas e o crescimento das redes de narcotráfico se associam ao tema do consumo de substâncias ilícitas/lícitas, a partir da década de 1990. Desse modo, o tema da criminalidade atravessa permanentemente o debate sobre as políticas públicas para os jovens. Na esteira dos indicadores sociais e no clamor público do combate à violência, no segundo mandato consecutivo de FHC, se desenham ações que teriam a pretensão de se constituírem em instâncias coordenadoras de políticas de juventude. Sob a égide da segurança pública foi criado o Programa do Gabinete de Segurança Institucional da Presidência da República, sob o controle de um general do exército, num claro simbolismo da "guerra" que deveria se travar pela salvação da juventude das garras do crime, do tráfico e da violência.

A Constituição federal de 1988 instaurou um novo ordenamento constitucional costurado com os fios de uma superior consciência de direitos e cidadania. $\mathrm{Na}$ esteira da mobilização democrática da sociedade brasileira, surgiram canais de participação da sociedade civil na formulação e na gestão das políticas públicas em áreas relacionadas com os sistemas de garantia de direitos e proteção de crianças e adolescentes - ECA e Plano Nacional dos Direitos Humanos. A promulgação do ECA, em 1990, foi o principal indutor de políticas sociais destinadas a crianças e adolescentes, sobretudo na Secretaria Nacional de Direitos Humanos do Ministério da Justiça. Programas e ações foram criados, não mais com base na ideologia do menor em situação irregular, mas na doutrina cidadã de proteção integral aos adolescentes em conflito com a lei.

A Lei Orgânica de Assistência Social (LOAS), aprovada em 1993, estabeleceu a criação do Sistema Descentralizado e Participativo da Assistência Social, do qual emergirão também ações na área da adolescência e da juventude. Por sua vez, o ano de 1997, data do assassinato do índio Galdino no Distrito Federal, traduz um marco importante que se expressa em respostas programáticas também à violência de jovens oriundos das classes médias.

No final da década, os indicadores sobre o desemprego juvenil e a acentuação dos processos de precarização social fomentam a necessidade de políticas de inclusão (tanto assistenciais como de promoção, para um patamar diferencial de integração na sociedade) em uma crise da ação de um Estado que durante toda a década de 1990 e o início do novo século viveu a hegemonia das políticas neoliberais.

Ainda que parcialmente, tais medidas oxigenam as políticas governamentais que incidem sobre a juventude com o arejamento promovido pela participação da sociedade civil. Entretanto, naquilo que se refere ao conjunto da população jovem, especialmente aqueles maiores de 18 anos que não mais estão sobre a proteção incondicional do ECA, inexistem formas democráticas e colegiadas de relacionamento participativo. $\mathrm{Na}$ cionalmente, no Brasil, ainda estão por se constituir conselhos e fóruns que canalizem a interlocução de jovens e demais atores com o estado na direção da definição política e da implementação prática de pautas ampliadas de garantia dos direitos universais à juventude.

$\mathrm{Na}$ análise do conjunto de programas e projetos classificados pela sua maior ou menor intensidade de foco na juventude, destacou-se o fato de esses programas serem recentes. É significativa a informação de que $60 \%$ dessas ações foram implantadas somente nos últimos cinco anos, o que denota a recente trajetória na formulação de políticas de juventude, assim como explica, em parte, a sua incipiente institucionalização e fragmentação.

As ações desarticuladas e a superposição de projetos com objetivos, clientela e área geográfica de atuação comuns, exprimem a frágil institucionalidade das políticas federais de juventude. As diferenças de concepções, longe de significarem a pluralidade dos que dialogam, revelam a incomunicabilidade no interior da máquina administrativa.

A depender do local de onde partem, os sentidos políticos e sociais das ações mudam, assim como o 
recorte etário do público-alvo; alguns ministérios se dedicam à assistência, alguns pretendem a inclusão dos “jovens carentes” e outros dão um caráter profilático às suas ações, implementando medidas saneadoras para evitar a violência. Mais recentemente emergem projetos e programas que pautam suas ações pela defesa da promoção da cidadania - noção evidente em muitos documentos oficiais, mas de pouca visibilidade nos desenhos e conteúdos teórico-metodológicos que guiam a implementação das ações nos municípios por equipes técnicas de organizações não-governamentais e prefeituras municipais, que se ressentem de acompanhamento político-pedagógico, suporte administrativo e avaliação de suas práticas.

Alguns programas assumiram sobremaneira o fetiche da capacitação do jovem para um mercado de trabalho de poucas oportunidades, sem propor qualquer caminho de questionamento da realidade econômica e social de um período histórico que viveu a recessão provocada pelas altas taxas de juros e os efeitos agudos da crise do mundo do trabalho. $\mathrm{O}$ acesso à informação também se apresentou como uma panacéia capaz de superar o isolamento sociocultural dos jovens, tanto aqueles das periferias das grandes cidades quanto os do interior rural.

Dois conceitos vigoraram em documentos de órgãos do governo federal e organizações não-governamentais, principalmente quando referentes a projetos e programas fortemente focados na juventude: protagonismo juvenil e jovens em situação de risco social. Aliás, essas idéias foram marcadas mais por apelo social do que conceitos ancorados em diagnósticos sociais e reflexões analíticas sobre o tema da juventude. Na grande maioria dos casos, representaram simplificações facilitadoras do entendimento de realidades sociais e culturais complexas e também códigos de acesso para financiamentos públicos orientados por uma tão nova quanto frágil conceituação de proteção social e cidadania participativa. Estimular $o$ protagonismo juvenil, expressão tantas vezes encontrada em textos de projetos variados, parece ser autoexplicativa até o momento em que nos perguntamos sobre o seu verdadeiro significado.
A busca por conceber e dirigir programas para jovens considerados carentes ou em situação de risco social, com a delimitação geográfica em municípios de baixo IDH, expressou políticas de focalização no combate à pobreza que predominaram nos governos do presidente Fernando Henrique Cardoso em detrimento de políticas de caráter universal.

Pelo que vimos, torna-se legítimo indagar: O que unifica as diferentes iniciativas federais nesse contexto de ampla diversidade de propósitos e práticas? O diagnóstico que emerge dos dados empíricos, ainda que preliminar, indica que o Brasil, do ponto de vista global, optou por um conjunto diversificado de ações muitas delas efetivadas na base do ensaio e do erro -, na falta de concepções estratégicas que permitam delinear prioridades e formas orgânicas e duradouras de ação institucional que compatibilizem interesses e responsabilidades entre organismos do Estado e da sociedade civil. Nesse sentido, é possível afirmar que a herança deixada pelo governo incide mais sobre projetos isolados, sem avaliação, configurando a inexistência de um desenho institucional mínimo que assegure algum tipo de unidade que nos permita dizer que caminhamos na direção da consolidação de políticas e formas democráticas de gestão.

Projetos e programas são concebidos na esfera federal - por servidores públicos e agentes de organizações não-governamentais consorciadas - e executados por municípios que, ansiosos por verbas federais, não questionam diretrizes, métodos e metas pré-fabricadas. Por sua vez, as organizações nãogovernamentais e demais grupos da sociedade civil acabaram por se conformar ao modelo proposto perante o pacote federal de ações. Buscaram, muitas vezes, com base nas estreitas faixas de ação autônoma, imprimir contornos próprios mais próximos de seus objetivos institucionais. Por essas razões, como a realidade das cidades é mais complexa que as correias de transmissão da centralização política, há sempre a possibilidade de saídas locais, tanto envolvendo a gestão criativa e participativa dos recursos quanto a reprodução dos velhos clientelismos políticos no trato com jovens "participantes" das ativida- 
des propostas por programas induzidos pelo poder central.

Está ainda por ser feito o inventário dos relacionamentos entre as organizações não-governamentais e os poderes públicos, no sentido de diferenciar aquilo que efetivamente se configurou como parceria entre o Estado e a sociedade civil organizada ou se consolidou simplesmente como forma mercantil de prestação de serviços no já denominado "mercado (do) social".

Existe, portanto, em todo esse processo de relacionamento entre a esfera federal, os estados e os municípios, o paradoxo de que, mesmo no contexto de políticas de execução descentralizada, os órgãos federais se constituem num poderoso indutor não democrático de políticas que conformam os programas localmente, apesar da delegação de verbas e responsabilidades. O balanço geral sobre os 33 programas e projetos federais relacionados, especialmente naquilo que se refere às ações voltadas para os jovens maiores de 18 anos, permite afirmar que inexistem canais democráticos que assegurem espaços de debates e participação para a formulação, o acompanhamento e a avaliação dessas ações.

\section{Iniciativas emergentes de políticas de juventude em nível local}

Outro movimento, nascido com base em instâncias do Poder Executivo local ou regional, também começa a ser delineado no final dos anos de 1990, no Brasil, quando tem início uma preocupação mais sistemática com a formulação e a implantação de algumas ações específicas voltadas para a juventude.

Não resta dúvida que, sob o ponto de vista dessas mudanças, o poder local - sobretudo a gestão municipal - oferece um campo significativo para a análise, em virtude de algumas características presentes no processo de democratização da sociedade brasileira a partir da década de 1980.

O município como foco de ações inovadoras decorre não só de um novo desenho da ação do Estado e de alguns dos mecanismos descentralizadores propostos na reforma dos aparatos estatais (Pereira, Wilheim
\& Sola, 1999; Draibe, 1998). ${ }^{22}$ O poder municipal aparece como campo privilegiado de análise porque nele as relações entre sociedade civil e Estado, para a conformação de uma esfera pública democrática, aparecem de forma mais clara. ${ }^{23}$ Os estudos de movimentos sociais, desde o início da década de 1980, têm procurado demonstrar as possibilidades de conflito e de interação negociada entre os vários atores sociais que têm como cenário a cidade (Castells, 1980, 1983; Kowarick, 1988).

Nessa arena conflitiva, ${ }^{24}$ o poder municipal aparece como interlocutor próximo dos grupos organizados, sobretudo quando as demandas giram em torno de transformações da qualidade de vida e de novas apropriações do espaço citadino. Por outro lado, é exatamente nesse plano que as políticas públicas no Brasil têm mais ousado na inovação, sobretudo nas administrações de caráter progressista sob a responsabilidade de partidos de esquerda ou de centro-esquerda. Porém, não é possível desconhecer a permanência de alguns núcleos duros (Lechner, 1990) da cultura política nacional, nos quais o poder local aparece como

${ }^{22}$ Por outro lado, é preciso reconhecer que parte significativa das ações federais tende a ser implantada por meio de parceiras com organizações não-governamentais ou mediante sistemas de distribuição de recursos que encontram no Poder Executivo municipal um canal importante de execução de programas e ações.

${ }^{23}$ Não se trata aqui de recuperar toda a discussão de sociedade civil e esfera pública observada nas ciências sociais no Brasil, mas de reconhecer que o conceito de sociedade civil adquire maior visibilidade sobretudo com o processo de democratização (Avritzer, 1993; Dagnino, 2002; Reis, 1995; Costa, 1994, 1997). Lourdes Sola (1998) considera que, não obstante a diversidade de modos de abordagem, há pontos de forte convergência entre os autores quando examinam a cultura política, os valores e os desenhos institucionais como elementos importantes a conformar a sociedade civil em uma perspectiva democrática.

${ }^{24}$ Os conflitos que nascem no tecido urbano incidem, em grande parte, sobre formas diversas de apropriação da cidade, que opõem relações mercantis dominadas pelo valor de troca e relações que têm como meta a fruição ou o valor de uso. 
foco privilegiado para o estabelecimento do clientelismo. Por essas razões, alguns autores, como Abad (2002), tratam também do surgimento do neolocalismo como uma das práticas que afetam negativamente a constituição dos espaços democráticos e de políticas públicas de juventude.

Essas considerações remetem para um eixo importante de problemas na concepção, na implementação e na avaliação das políticas municipais, que é $O$ modo como são estabelecidas as relações com os próprios segmentos juvenis destinatários das políticas. Serão estes parceiros e atores relevantes ou apenas usuários potenciais dos programas? Não sem razão, Sola procura distinguir políticas de feitio corretivo ou compensatório daquelas que seriam transformadoras, pois as últimas permitiriam "a incorporação dos jovens também nos processos mais densos de socialização civil" (1998, p. 762). Abad (2002) também sugere outros aspectos importantes no exame das políticas que exprimiriam concepções em torno dos possíveis destinatários das ações - os jovens. Algumas políticas poderiam ter adquirido formato especialmente inclusivo ou integrador (sobretudo em situações de crise social e de mecanismos de exclusão), mas privilegiaram na sua acepção de juventude a preparação para a vida adulta (voltadas para o futuro). $\mathrm{Ou}-$ tras poderiam ser situadas no recorte afirmativo de direitos que buscariam sobretudo a autonomia e a autodeterminação dos jovens no próprio momento do ciclo de vida (voltadas para o presente).

Observa-se, a partir de meados dos anos 1990, nos planos local e regional, o aparecimento de organismos públicos destinados a articular ações no âmbito do poder executivo e estabelecer parcerias com a sociedade civil, tendo em vista a implantação de projetos ou programas de ação para jovens, alguns financiados pela esfera federal. ${ }^{25}$ Esse fato é bastante re-

${ }^{25}$ Durante o ano 2000, a Ação Educativa, organização nãogovernamental voltada para o trabalho com os segmentos juvenis, por meio de sua rede de parceiros e colaboradores, empenhouse em identificar organismos públicos, nas esferas municipal e cente e decorre sobretudo de compromissos eleitorais de partidos, principalmente de esquerda e de centroesquerda, ${ }^{26}$ que, por meio de sua militância juvenil ou de setores organizados do movimento estudantil, incluíram na sua plataforma política demandas desses segmentos que aspiravam pela formulação de ações específicas destinadas aos jovens. ${ }^{27}$

Constata-se que debates e programas desenvolvidos por organizações não-governamentais foram importantes como fomentadores de novas idéias para a ação do governo municipal. Tudo leva a crer que, antes de serem incorporados pela esfera governamental, programas e eventuais políticas destinados aos jovens já vinham sendo experimentados pela sociedade civil por meio das organizações não-governamentais e de fundações empresariais, recobertos de extrema diversidade quanto às orientações (Rua, 1998).

Ao que tudo indica, o ano 2001 exprime uma in-

estadual, voltados especialmente para a implantação, a coordenação e a execução de ações destinadas aos jovens no Brasil. Nesse esforço, que não pretendeu ser exaustivo e nem ter o caráter de amostragem estatística, foi possível identificar, ao todo, 24 instâncias governamentais. Os comentários feitos têm por base algumas das informações obtidas em um levantamento realizado por Bruna Mantese de Souza, aluna do curso de Ciências Sociais da USP e estagiária da Ação Educativa, em cujos arquivos o referido o levantamento está disponível.

${ }^{26}$ Se considerarmos o ano de criação, verificamos que a maioria teve início nas gestões municipais concluídas em 2000. As iniciativas identificadas cobrem praticamente todos os grandes partidos brasileiros: cinco organismos criados em gestão do Partido dos Trabalhadores; cinco de partidos no campo de centroesquerda que realizaram alianças no segundo turno com o candidato Lula, para as eleições presidenciais de 2002 (um do PDT, dois do PPS e um do PSB); dois do PFL (partido à direita do espectro político); e, finalmente, dois do PSDB.

${ }^{27}$ Metade dos organismos identificados afirmava ter contemplado a proposta em seus planos de governo. No entanto, percebe-se que não há um modelo claro de referência para a sua criação, uma vez que da carta de intenções à implantação das políticas cria-se um interregno que permite formatos diversos. 
flexão importante no processo de constituição de políticas públicas destinadas aos jovens. Trata-se do primeiro ano de novas gestões no âmbito municipal, período que marca uma ampliação desses novos organismos. Por outro lado, somente uma perspectiva longitudinal, incorporando uma série histórica maior, poderá aferir tendências, descontinuidades e formas de consolidação de uma nova institucionalidade nas políticas de juventude no Brasil. ${ }^{28}$

Verifica-se que são iniciativas nascidas sobretudo em capitais de estados ou em cidades pequenas e médias, indicando a existência de considerável diversidade de desafios diante das condições populacionais, do desenvolvimento urbano e de formas de gestão coletiva dos espaços e equipamentos públicos. Em contrapartida, torna-se evidente a lacuna diante dos jovens que vivem no campo, se considerarmos a amplitude dos problemas agrários que o Brasil vive e a existência de movimentos e organizações sociais bastante atuantes no campo. Assim, o tema das políticas públicas de juventude no Brasil está sendo delineado ainda sob uma perspectiva estritamente urbana.

Os novos organismos assumem predominantemente o caráter de assessorias, embora em algumas situações sejam criadas secretarias de estado ou coordenadorias. No elenco desse novo desenho institucional estão localizados também os Conselhos de Juventude, tanto municipais como estaduais, com formatos e funções diversos. Ação bastante inovadora constitui a abertura institucional para a presença jovem nas várias etapas que marcam a discussão e a implantação do Orçamento Participativo em alguns municípios. Essa experiência, iniciada em Porto Alegre na gestão do Partido dos Trabalhadores (Santos, 2002; Avritzer, 2002), constitui referência importante de proposta de uma nova modalidade de relação

${ }^{28}$ Em novembro de 2002, em seminário sobre o tema das "Políticas Públicas de Juventude", promovido pela Ação Educativa, foram identificados, dentre os inscritos, quatro organismos em nível estadual e 22 em nível municipal voltados para ações específicas de políticas de juventude. entre governo e sociedade que tende a se disseminar em vários municípios do país. Nesse conjunto foram identificadas algumas cidades onde a presença e a participação da juventude foram intencionalmente defendidas pelos gestores públicos e traduzidas em mecanismos específicos que as assegurassem. ${ }^{29}$

Observa-se, também, uma grande variedade de formas de alocação do órgão na estrutura administrativa do Estado, alguns vinculando-se diretamente ao chefe do executivo local ou regional. Diante do caráter emergente da ação e de sua institucionalidade, começa a ser criado um consenso inicial com base nessas experiências: que essa proximidade poderia proporcionar uma correlação de forças mais favorável do ponto de vista das decisões políticas, uma vez que a burocracia governamental tenderia a não incorporar de modo claro novos organismos que não estão suficientemente recobertos de legitimidade política e institucional. ${ }^{30}$

De certa forma, o caminho a ser constituído parece ser o inverso da luta pelos direitos da infância e da adolescência. Nesse caso, um amplo movimento social lutou, inicialmente, por um desenho jurídico que assegurasse direitos e formas de execução e buscou, em seguida, sua implantação. No caso das políticas de juventude, na ausência de atores coletivos estruturados fortemente em nível nacional baseados na temática da juventude e de projetos políticos cla-

${ }^{29}$ Há uma diversidade de situações e de resultados dessa forma inovadora que merece ainda uma investigação. Nem todas as experiências vingaram e conseguiram imprimir certa continuidade, como é o caso da cidade de Santo André, na região metropolitana de São Paulo. Outras mostraram sua potencialidade organizativa, como é o caso de Betim, Uberlândia e Itabira, em Minas Gerais. A cidade de Belém construiu uma experiência pioneira bem-sucedida, que evoluiu para uma organização da presença do jovem na formulação das políticas para a cidade e tem constituído referência para outros municípios.

${ }^{30}$ Uma das expressões da inexistência de legitimidade consolidada decorre da ausência de orçamento próprio para a maioria desses organismos. 
ros para esse segmento no âmbito federal, começa a emergir, a partir da base, um conjunto heterogêneo de práticas. Essa diversidade, se de um lado recobre a possibilidade de experimentação e de inventividade social, elementos importantes para a constituição da democracia, de outro poderá resultar em experiências fragmentadas, com fraco poder de impacto e de disseminação não favorável à criação de elementos consistentes de uma nova cultura política na formulação de ações para a juventude.

Quando se analisa o conjunto de motivações que as ações propõem, observa-se que, mesmo conformadas por gestões municipais de caráter progressista, as representações normativas correntes exprimem ainda a idéia básica de superação dos problemas vividos pelos jovens, sua situação de vulnerabilidade e, portanto, a meta fixada incide sobre o combate a esses problemas (desemprego, violência, drogas). Verifica-se que nas percepções há, também, um conjunto de referências ligadas às novas desigualdades e processos de exclusão decorrentes das conjunturas neoliberais que atingem sobretudo o segmento juvenil, e que, por essas razões, são demandadas ações específicas para esses segmentos. Convivem com essas orientações algumas práticas que exprimem o reconhecimento de direitos e a admissão de necessidades a serem satisfeitas por políticas (emprego, saúde, lazer, educação, cultura etc.). Observam-se práticas capazes de reconhecer os jovens como sujeitos capazes de participação - sobretudo nas experiências do Orçamento Participativo - e, em caráter minoritário, ações voltadas para os processos de construção de auto-estima e de identidade juvenis, com base no diálogo com as formas coletivas pelas quais esses segmentos se organizam.

Mesmo assim, deve-se reconhecer que as motivações exprimem algumas limitações como campo privilegiado para compreensão das políticas, pois entre a formulação dos princípios e as ações podem ocorrer filtros, correções e eventuais alterações que somente estudos qualitativos aprofundados das práticas podem elucidar.

No entanto, é preciso admitir que parte significativa de uma incipiente vontade política de constru- ção das ações públicas decorre do reconhecimento dos problemas que afetam a juventude. Parte dessas percepções, de certa forma, pode passar a considerar que o próprio jovem se torna um problema para a sociedade, e é sob essa ótica que o poder público deve tratá-lo (Abramo, 1997). Outro conjunto pode transformar os problemas concretos vividos pelos jovens em necessidades que se inscrevem no campo dos direitos, alargando a pauta de ação e os compromissos da esfera pública - governamental e não-governamental - para com esses segmentos: direito ao trabalho, ao lazer, à cultura, à escola etc.

Certo consenso já é revelado em torno da necessidade de articulação e coordenação de programas e projetos já existentes, e não a mera ampliação das ações. Se os gestores municipais têm por função primordial essa articulação, torna-se evidente que não pretendem cultivar um isolamento no desenho da burocracia estatal, implicando certa recusa em centralizar todas as ações, o que poderia resultar, na melhor das hipóteses, em incapacidade de ação.

Torna-se importante considerar que desenhos institucionais novos no âmbito da máquina estatal lutam por espaços de reconhecimento, de interferência e de poder diante de estruturas pesadas, burocráticas e já enraizadas na administração pública. Por essas razões, é preciso tornar efetiva a capacidade de articular ações e parcerias e evitar que aos organismos reste apenas uma função decorativa e, de certa forma, apaziguadora de uma certa pressão de jovens e demais setores da sociedade civil, quando essa incipiente institucionalidade de forma geral é marcada pela ausência de poder nas relações de governabilidade no interior do Poder Executivo municipal. ${ }^{31}$

Quanto ao público-alvo das ações, é possível

${ }^{31}$ Como há o problema da ausência de recursos orçamentários próprios, de um status definido do gestor nessa inter-relação, parte do trabalho permanece no plano das intenções e decorre mais do voluntarismo político de alguns, que de um esforço coletivo da gestão em conviver com novos e emergentes desenhos institucionais. 
depreender que a faixa etária de abrangência dos programas é ampla: dos 14 aos 24 - faixa estabelecida pela Organização das Nações Unidas (ONU); embora alguns ampliem essa faixa até 29 anos, como define a Organização Internacional da Juventude (OIJ). Percebe-se que há uma prioridade para os jovens/adolescentes mais pobres ou aqueles considerados em "condição de risco pessoal e social". Outros municípios trabalham com jovens integrados no sistema de ensino, e alguns mostram vocação para trabalho com os jovens em geral, sem definição de variáveis de natureza socioeconômica.

Por outro lado, mesmo reconhecendo a diversidade de ações presentes nos municípios, é preciso investigar em que medida elas sinalizam para a formulação de políticas, implicando coordenação de esforços. Importa, também, verificar em que medida reiteram ou impõem rupturas com padrões tradicionais da cultura política administrativa brasileira, traduzidos por Rua (1998) em cinco regularidades: fragmentação, competição interburocrática, descontinuidade administrativa, ações com base na oferta e não da demanda e, finalmente, a existência de uma clara clivagem entre a formulação/decisão e a implantação.

As ações desenvolvidas por esses organismos recobrem inevitável heterogeneidade, pois não exprimem desenhos claros sobre projetos de desenvolvimento social e respectivo lugar da juventude no interior dessa proposta global. O mundo do trabalho e algumas ações consideradas de inclusão têm ocupado parte importante das ações, ao lado da criação de alguns equipamentos específicos para jovens (centros de juventude, por exemplo). Verifica-se, também, práticas que buscam afirmar direitos de jovens relativos à sua participação e à sua formação como atores sociais (cursos, seminários, oficinas) e menos voltados para a realização de eventos fragmentados sem proposta de continuidade. As ações são realizadas em parceria, envolvendo tanto outros órgãos governamentais como organizações da sociedade civil.

Uma das características desses organismos é a presença de jovens na função de gestores. Em geral são jovens oriundos de setores militantes, sobretudo do movimento estudantil e de partidos políticos. Essa situação conforma um conjunto de desafios que poderão proporcionar caminhos diversos na constituição das políticas de juventude.

O primeiro incide sobre os eventuais problemas derivados de um eventual privilégio das ações e de interação com grupos juvenis com maior grau de institucionalidade, pois em geral esses quadros são provenientes de grupos organizados do movimento estudantil ou dos partidos que são responsáveis pela administração. As formas menos orgânicas dos coletivos juvenis que se originam na cidade - sobretudo aquelas derivadas do mundo da cultura, do lazer e da ação voluntária - têm, em geral, ocupado menos espaço, não apenas enquanto público destinatário das ações ou equipamentos, mas sobretudo enquanto atores relevantes na formulação das ações. Isso remete a uma questão de natureza mais complexa do que aquelas que até então têm sido pautadas nas análises e nos estudos sobre políticas de juventude. Trata-se, de um lado, do reconhecimento, hoje consensual, de novos agenciamentos capazes de fomentar a ação coletiva juvenil para além dos espaços consagrados da política institucional partidária ou do movimento estudantil. Mas, por outro lado, quando o campo é relativo à disputa de posições de poder ou de capacidade de interferência, a arena pública ainda privilegia formas organizativas tradicionais como âmbito específico de possibilidade de ação e, sob esse ponto de vista, os novos agrupamentos juvenis são frágeis.

O caráter ainda precário de inserção administrativa no organismo no aparelho público faz com que os gestores jovens devam dispender um esforço adicional. Além da busca de reconhecimento da necessidade das políticas de juventude e do organismo do qual participa - muitas vezes um setor estranho em estruturas pesadas -, é preciso percorrer um caminho de legitimidade que decorre de sua condição juvenil. No interior da burocracia, os recortes de idade e de geração também se fazem presentes, com as inevitáveis fontes de tensão no cotidiano das interações. Resta sempre a possível permanência de formas de dominação do mundo adulto sobre o jovem, não importando 
a fonte que eventualmente recobriria sua legimitidade: autoridade, maior experiência, melhor qualificação técnica, entre outras. Se as relações entre as idades são recobertas de hierarquias e de formas de exercício de poder, é importante que elas não sejam obscurecidas, pois podem encobrir processos de confinamento e isolamento dos gestores, que exprimiriam perdas consideráveis para a implantação das políticas destinadas aos jovens.

Finalmente, é preciso considerar que a existência do gestor jovem não significa, a priori, a condição para a formulação de políticas mais adequadas, sob pena de certa naturalização e homogeneização da condição juvenil, intensamente criticada no debate público. Por essas razões, outra questão importante diz respeito ao perfil técnico e às formas de qualificação dos gestores, tendo em vista ainda o caráter inovador das políticas. Há um longo caminho a ser percorrido, que permitirá definir melhor qual seria o conjunto de competências mínimas para o exercício do cargo, para além de um claro horizonte de premissas sobre o caráter das políticas a serem construídas.

Uma última indagação sobre gestores e funções dos organismos incide sobre a natureza da relação a ser mantida com os segmentos juvenis. Tendo em vista o caráter bastante inicial dessas ações, percebe-se que, quanto aos jovens, o diálogo se faz de modo individual ou nos programas desenvolvidos, mas sem, ainda, a existência de mecanismos que consagrem a presença juvenil de forma a constituir uma parceria articulada. Buscou-se em algumas cidades a criação de fóruns ou conselhos de juventude, tanto no nível estadual como no municipal, e a implantação de conselhos gestores de centros de juventude. Mesmo não havendo clareza do melhor caminho para que as ações sejam desenvolvidas com a juventude, percebe-se que o tema da participação dos jovens na formulação, implantação, execução e avaliação das políticas está, ao menos, no horizonte das ações.

Mais uma vez, percebe-se que a presença de atores coletivos juvenis diversificados asseguraria, em tese, o caráter plural e democrático da participação. O caráter emergente dessa nova agregação dos inte- resses e da sociabilidade juvenil no âmbito da cidade, muito mais ligada a formas expressivas, resistentes a certa racionalidade instrumental inerente ao mundo da política institucional, abre para um novo campo de conflitos e de ações que poderão, de certo modo, contribuir para uma reinvenção da esfera pública, na esteira dos movimentos sociais observados a partir dos anos de 1970 na sociedade brasileira.

\section{Finalizando?}

O Governo Lula, empossado em janeiro de 2003, herda alguns desafios importantes e de difícil equacionamento. Não só precisa contribuir efetivamente para a construção de um modo diverso de compreensão dos jovens na sociedade brasileira, a ser expresso tanto sob a forma de políticas públicas democráticas que reconhecem o não-cumprimento de direitos historicamente negados - educação, saúde e trabalho -, como capaz de se abrir para outras modalidades de ação que contemplem novos direitos da juventude.

Mas o atual governo federal se encontra, também, em um campo de disputa de orientações. Nesse terreno conflituoso existe a possibilidade da elaboração de políticas que contrariem as orientações dominantes e redutoras da complexidade dos fenômenos sociais. É preciso avançar para além das doutrinas de segurança pública e de assistência social no trato com as políticas públicas federais orientadas para os jovens. Sem negligenciar as inúmeras dificuldades de ampliação das dotações orçamentárias para as políticas públicas sociais, admite-se que o desafio maior é, contudo, inscrever as políticas de juventude em uma pauta ampliada de direitos públicos de caráter universalista. Essas orientações devem pressupor os jovens como sujeitos dotados de autonomia e como interlocutores ativos na formulação, execução e avaliação das políticas a eles destinadas.

MARÍLIA PONTES SPOSITO é professora titular em sociologia da educação na Faculdade de Educação da Universidade de São Paulo e presidente da Ação Educativa. Principais publicações: O povo vai à escola; a luta popular pela expansão do ensino 
público em São Paulo (São Paulo: Loyola, 1984); A ilusão fecun$d a$; a luta por educação nos movimentos populares (São Paulo: Hucitec e EDUSP, 1993); O trabalhador-estudante; um perfil do aluno do curso superior noturno (São Paulo: Loyola, 1989, em colaboração). Coordenou a pesquisa e a publicação de Juventude e escolarização - 1980/1998 (Brasília: INEP/MEC, 2003, Série Estado do Conhecimento $\mathrm{n}^{\circ}$ 7). Coordena atualmente o projeto de pesquisa Juventude, Escolarização e Poder Local, em parceria com Sérgio Haddad e com o apoio do CNPq e da FAPESP.

PAULO CÉSAR RODRIGUES CARRANO é professor da Faculdade de Educação da Universidade Federal Fluminense, vinculado ao Programa de Pós-Graduação em Educação, no qual se doutorou em 1999. Publicou recentemente: Os Jovens e a cidade: identidades e práticas culturais em Angra de tantos reis e rainhas (Rio de Janeiro: Relume Dumará/FAPERJ, 2002) e Juventudes e cidades educadoras (Petrópolis: Vozes, 2003); em co-autoria com Juarez Dayrell, Jovens no Brasil: difíceis travessias de fim de século e promessas de um outro mundo (In: Trayectorias y travesías juveniles en el Cono Sur. México, DF: Revista JOVENes, ${ }^{\circ} 17$, 2003). Pesquisador do CNPq e favorecido com o apoio da FAPERJ na modalidade "Cientistas do Nosso Estado" para a pesquisa Juventude e Poder Local na Região Metropolitana do estado do Rio de Janeiro, parte da pesquisa Juventude, Escolarização e Poder Local, coordenada por Marília Pontes Sposito e Sérgio Haddad. Coordena ainda o Observatório Jovem do Estado do Rio de Janeiro, com sede na UFF.

\section{Referências bibliográficas}

ABAD, Miguel, (2002). Las politicas de juventud desde la perspectiva de la relacion entre convivencia, ciudadania y nueva condicion juvenil. Última Década, Viña del Mar, CIDPA, $\mathrm{n}^{\mathrm{o}} 16$, p. 119-155, mar.

ABRAMO, Helena, (1997). Considerações sobre a tematização social da juventude no Brasil. Revista Brasileira de Educação, $\mathrm{n}^{\circ}$ 5/6, p. 25-36, maio-dez. (Número especial sobre Juventude e Contemporaneidade).

ATTIAS-DONFUT, Claudine, (1996). Jeunesse et conjugaison des temps. Sociologie et Sociétés, v. 28, n 1, p. 13-22.

AVRITZER, Leonardo, (1993). Além da dicotomia Estado-mercado: Habermas, Coehn e Arato. Novos Estudos Cebrap, São Paulo, no 36, p. 213-222.
, (2002). Modelos de deliberação democrática: um análise do orçamento participativo no Brasil. In: SANTOS, Sousa Boaventura (org.). Democratizar a democracia: os caminhos da democracia participativa. Rio de Janeiro: Civilização Brasileira, p. 561-598.

BOURDIEU, Pierre, (1986). De quoi parle-t-on quand on parle du “problème de la jeunesse"? In: PROUST, François (org.). Les jeunes et les autres: contributions des sciences de l'homme à la question des jeunes. Vaucresson: CRIV, p. 229-235.

CASTELLS, Manuel, (1980). Cidade, democracia e socialismo. Rio de Janeiro: Paz e Terra. , (1983). The city and the grassroots. Berkeley: University of California.

COSTA, Sérgio, (1997). Categoria analítica ou passe-partout político-normativo: notas bibliográficas sobre o conceito de sociedade civil. Revista Brasileira de Informação Bibliográfica em Ciências Sociais (BIB), São Paulo, n 43, p. 3-26. (1994). Esfera pública redescoberta da sociedade civil e movimentos sociais no Brasil: uma abordagem tentativa. Novos Estudos Cebrap, São Paulo, nº 38, p. 38-52.

DAGNINO, Evelina, (2002). Sociedade civil e espaços públicos no Brasil. Rio de Janeiro: Paz e Terra.

DRAIBE, Sônia M., (1998). Reforma do estado e descentralização: a experiência recente da política brasileira de ensino fundamental. Paper apresentado no Internacional Seminar "Restrycthyrubg and government reform: Brazil and Latin America in a globalization context", maio.

DURKHEIM, Émile, (1970). Sociologia e filosofia. Rio de Janeiro: Forense.

FERRETI, Celso João, (2000). Mudanças em sistemas estaduais de ensino em face das reformas no ensino médio e no ensino técnico. Educação \& Sociedade, ano XXI, $\mathrm{n}^{\circ}$ 70, p. 80-99, abr.

GOIÁS, Jussará de, (2002). As propostas do Congresso Nacional para crianças e adolescentes. Brasília: INESC.

KOWARICK, Lúcio (1988). As lutas sociais na cidade. Rio de Janeiro: Paz e Terra.

KUENZER, Acácia Zeneida, (2000a). O ensino médio agora é para a vida: entre o pretendido, o dito e o feito. Educação \& Sociedade, v. $21, \mathrm{n}^{\circ} 70$, p. 15-39, abr.

, (2000b). Ensino médio: construindo uma proposta para os que vivem do trabalho. São Paulo: Cortez.

LAGREE, Jean Charles, (1999). Age, jeunesse et politiques publiques. Paris, mimeo. 
LECHNER, Norberto, (1990). Los patios interiores de la democracia; subjetividad y política. Santiago: Fondo de Cultura Económica.

LEFEBVRE, Henri, (1980). La présence et l'absence: contribution à la théorie des représentations. Paris: Casterman.

PAIS, José Machado, (1993). Culturas juvenis. Lisboa: Imprensa Nacional, Casa da Moeda.

PEREIRA, L. C., WILHEIM, J., SOLA, Lourdes, (1999). Sociedade e estado em transformação. São Paulo: UNESP, Imprensa Oficial e ENAP.

REIS, Elisa, (1995). Desigualdade e solidariedade: uma releitura do "familismo amoral" de Banfield. Revista Brasileira de Ciências Sociais, São Paulo, no 29, p. 35-48.

RUA, Maria das Graças, (1998). As políticas públicas e a juventude dos anos 90. In: . Jovens acontecendo na trilha das políticas públicas. 2 v. Brasília: CNPD, p. 731-752.

SANTOS, Boaventura Sousa, (2002). Orçamento participativo em Porto Alegre: para uma democracia redistributiva. In: (org.). Democratizar a democracia; os caminhos da democracia participativa. Rio de Janeiro: Civilização Brasileira, p. 455-544.

SOLA, Lourdes, (1998). Juventude, comunidade política e sociedade civil. In: Jovens acontecendo na trilha das políticas públicas. Brasília: CNPD, p. 753-768.
SPOSITO, Marília Pontes (coord.), (1997). Estudos sobre juventude em educação. Revista Brasileira de Educação, São Paulo, $n^{\circ}$ 5/6, p. 37-52, maio-dez. (Número especial sobre Juventude e Contemporaneidade)

(2002). Juventude e escolarização (1980/1998).

Brasília: MEC/INEP/Comped (Estado do Conhecimento, 7).

\section{Sites consultados em dezembro de 2002}

Associação Brasileira de Magistrados e Promotores de Justiça da Infância e Adolescência - www.abmp.org.br

\section{$\mathrm{CNPq}-$ www.cnpq.br}

Comunidade Solidária - www.universidadesolidaria.org.br

Gabinete da Presidência - www.presidencia.gov.br/gsi/piaps

Ministério da Educação - www.mec.gov.br

Ministério da Justiça - www.mj.gov.br

Ministério da Previdência e Assistência Social - www.mpas.gov.br Ministério da Saúde - www.saude.gov.br

Ministério de Desenvolvimento Agrário - www.mda.gov.br

Ministério do Esporte e Turismo - www.met.gov.br

Ministério do Trabalho e Emprego - www.mte.gov.br

Recebido em junho de 2003 Aprovado em julho de 2003 